\section{The Bassi Historical International Library of Phlebology at the Ferrara University Hospital}

\author{
Marco Bresadola \\ Dipartimento Studi Umanistici, University \\ of Ferrara, Italy
}

\section{Abstract}

This year we celebrate the centenary of the birth of the Italian phlebologist Glauco Bassi, who played a principal role in the development of phlebology as a discipline, as well as in the Foundation of the Union Internationale de Phlebologie (UIP). Moreover, Bassi is not only a founding father of phlebology, but he represents an inspiring model for a medical teaching and practice centered on the doctor-patient relationship. In compliance with the will of Neso Onorina, the Bassi Fund heir, and of Dr. Lorenzo Tessari, her emissary and Bassi's pupil, the Glauco Bassi Foundation donated the Bassi Fund to the University of Ferrara. Following those principles of advanced research in the venous restoration rather than abolition that were transmitted from Glauco Bassi to Lorenzo Tessari, this last one identified in the Prof. Paolo Zamboni's academic vein Centre the right environment in which letting the research and innovation grow. In turn, to make the Bassi Fund scientific literature treasure available to the public community, with the hope of increasing the general awareness on venous restoration, Prof. Paolo Zamboni, world-wide recognized pioneer in the venous hemodynamics field, donated the Bassi Fund to the Library of the Health Sciences of the University Hospital of Ferrara, constituting a Scientific Committee of which he became President. The Bassi Library now lives at the Cona Hospital and is daily attended by students, residents, PhD, and people interested in phlebology as well.

\section{The Centenary of Glauco Bassi's birth and the International Historical Library of Phlebology}

This year we celebrate the centenary of the birth of the Italian phlebologist Glauco Bassi, who was born in Feltre, a village in the northeast of Italy, on $19^{\text {th }}$ of December 1914 (Figure 1). While most physicians know his name after some small veins of the calf (Bassi's perfora- tors), not so many know his role in the birth of phlebology as a discipline and still fewer know his scientific contributions and personality in detail. This is really unfortunate, as Bassi is not only a founding father of phlebology, but he represents an inspiring model for a medical teaching and practice centered on the doctorpatient relationship. In compliance with the will of Neso Onorina, the Bassi Fund heir, and of Dr. Lorenzo Tessari, her emissary and Bassi's pupil, the Glauco Bassi Foundation donated the Bassi Fund to the University of Ferrara. Following those principles of advanced research in the venous restoration rather than abolition that were transmitted from Glauco Bassi to Lorenzo Tessari, this last one identified in the Prof. Paolo Zamboni's academic vein Centre the right environment in which letting the research and innovation grow. In turn, to make the Bassi Fund scientific literature treasure available to the public community, with the hope of increasing the general awareness on venous restoration, Prof. Paolo Zamboni, world-wide recognized pioneer in the venous hemodynamics field, donated the Bassi Fund to the Library of the Health Sciences of the University Hospital of Ferrara, constituting a Scientific Committee of which he became President. The Bassi Library now lives at the Cona Hospital and is daily attended by students, residents, PhD, and people interested in phlebology as well (Figure 2).

In the Library there are also documents and letters testifying the first contacts among the fathers of Phlebology immediately after the Second World War. They are either political contacts about the organization of the first meeting in Europe and foundation of the Union International de Phlebologie, or scientific contacts regarding articles and first textbooks on venous disorders. The Library has been recently visited by the Union Internationale de Phlebologie (UIP) President Elect Nick Morrison, MD, and by many other leading people in Phlebology such as B.B. Lee, MD, and Joseph Raffetto, MD (Figure 3).

\section{The legacy of Glauco Bassi, a founding father of phlebology}

As Robert Stemmer, a former secretary of the UIP, wrote in a eulogy composed on the occasion of Bassi's seventieth birthday, visiting a patient with Bassi is a medical delight. And Jean van der Stricht, a former president of the UIP, strongly suggested that young phlebologists follow Bassi's recommendations in their daily practice and study his views before undertaking their research on the physiology and pathology of the veins. But the best portrait of Bassi is perhaps the one he himself wrote in his own obituary, composed some
Correspondence: Marco Bresadola, Dipartimento Studi Umanistici, University of Ferrara, via Paradiso 12, 44100 Ferrara, Italy.

Tel.: +39.0532.293412.

E-mail:marco.bresadola@unife.it

Key words: Bassi Foundation, Glauco Bassi, International Union of Phlebology.

Received for publication: 22 May 2014.

Accepted for publication: 22 May 2014.

This work is licensed under a Creative Commons Attribution 3.0 License (by-nc 3.0).

(C) Copyright M. Bresadola, 2014

Licensee PAGEPress, Italy

Veins and Lymphatics 2014; 3:4150

doi:10.4081/vl.2014.4150

months before his death, which occurred in December, 1987: Those who knew Bassi personally say that he had a good disposition but a difficult character. He easily lost his temper, and lacked tact and diplomacy. He was too honest and rigorous to be appreciated by most, but he never missed the esteem and friendship of the most eminent among his foreign colleagues.

In fact, Bassi was an international medical figure. He was much more appreciated by French and German physicians than by his Italian colleagues, and he himself looked beyond the Alps to develop a new conception of the functioning of the venous system and to establish more efficient therapeutic methods. Bassi's international standing is testified by his publications in many different languages and by his strenuous activity in European societies and worldwide conferences. His book $L e$ varici degli arti inferiori (The varicose veins of the inferior limbs) published in 1962 and with a new French edition in 1967, was considered the bible of the phlebologist by Raymond Tournay, the inventor of the term phlebology. Bassi published two other fundamental books on phlebology and more than a hundred articles in the major international journals. He spent more than thirty years treating patients in his medical practice in Trieste, and was also very interested in the teaching and popularization of medicine. He even produced a movie to communicate new views on the treatment of varicose veins. Last but not least, he actively participated in the construction of international networks of phlebologists, being one of the founders of the Union Internationale de Phlebologie and its vice-president for many years.

Bassi's multifarious and international activity is reflected in his medical library and archive, which is now kept in the library of the Sant'Anna Hospital in Ferrara, Italy. Bassi's library contains all the main journals and books on angiology and phlebology published 
until the end of the 1980s. His archive preserves his clinical notebooks, the texts of his conference papers, reviews, articles, and books, about three thousand pages of notes taken from his readings and reflections on phlebology, and his correspondence with the major phlebologists of his time. It is a real treasure, which allows reconstructing how phlebology emerged as a discipline and developed in his early four decades of life, from the 1950 s to $1980 \mathrm{~s}$. But it is also an archive of phlebological knowledge which today's physicians and researchers may consult to find fundamental information and original ideas on the physiology, pathology, and treatment of the venous system.

In what follows we shall give just two examples of the richness and interest of Bassi's archive, as well as of the fundamental role played by his activity in the emergence and development of phlebology. The first example concerns Bassi's role in the organization of the first world conference of angiology, which took place in Paris in 1952. In previous years Bassi had spent long periods of study in the French capital, where he had met some of the main angiologists of the time such as Louis Gerson, the organizing secretary of the 1952 conference. In a letter of October 1951, Gerson asked Bassi to give him a list of the Italian physicians active in the field and to set up an Italian committee of angiology. Bassi accepted the task, participated in the conference and established the first Italian association of phlebology with Marcello Comel and a few others. Some years later, in 1959, this group joined the French and German phlebological societies to form the UIP, which is still the most important medical association in the field.

A second example from Bassi's archive concerns the publication of his Compendio di terapia flebologica published in 1985, a compendium of phlebological theory to which nearly all the major phlebologists of the time gave their contribution. As had happened with his book on varicose veins, which had been translated into French, Bassi wanted to make his compendium accessible to an international audience. He wrote to Jean van der Stricht and André Davy, at the time president and secretary of the UIP, to propose them a Spanish edition of the compendium under the aegis of the society. Here is what van der Stricht answered in a letter of December, 1986: You do not ignore that UIP has planned the publication of a treatise aimed at the teaching of the fundamental aspects of phlebology, a work addressed to those

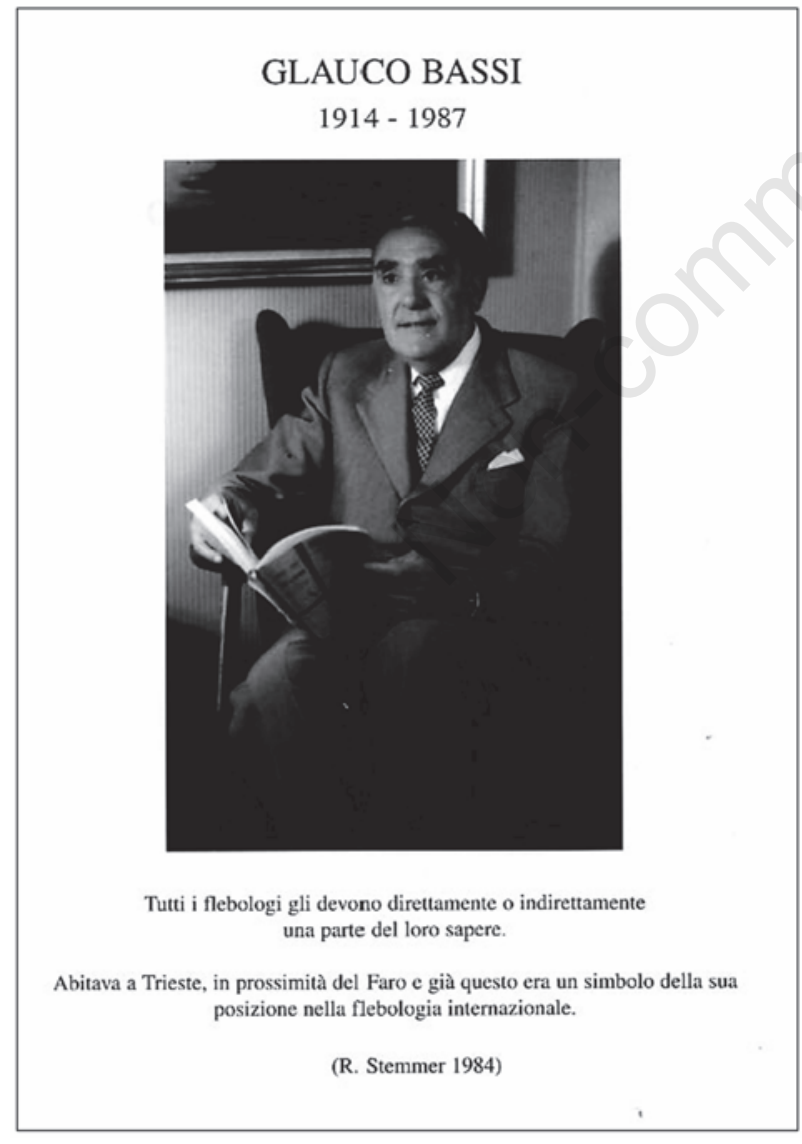

Figure 1. Glauco Bassi, MD. He lived in Trieste, Italy, close to the lighthouse, and according to Robert Stemmer, this was the symbol of his position in the International Phlebology World.

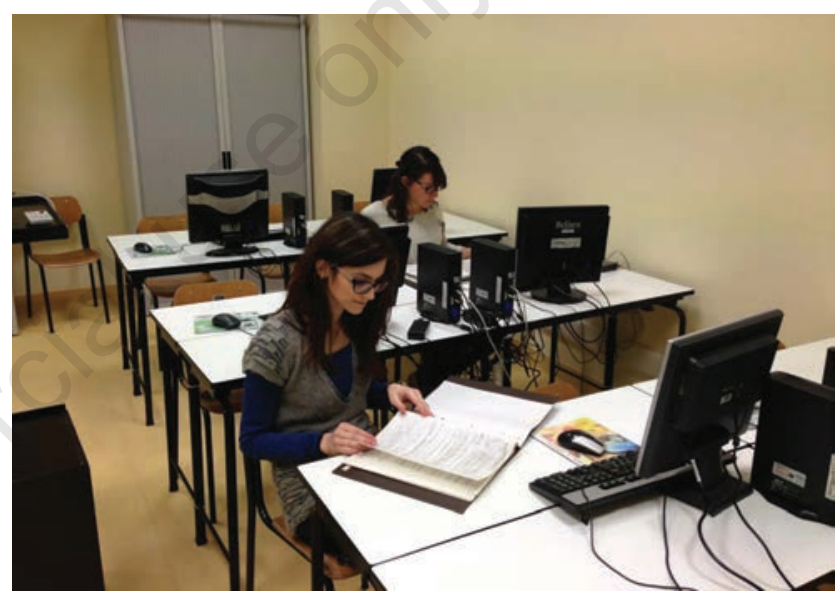

Figure 2. The Bassi clinical cases and the pioneering hypertext are consulted by medical students.

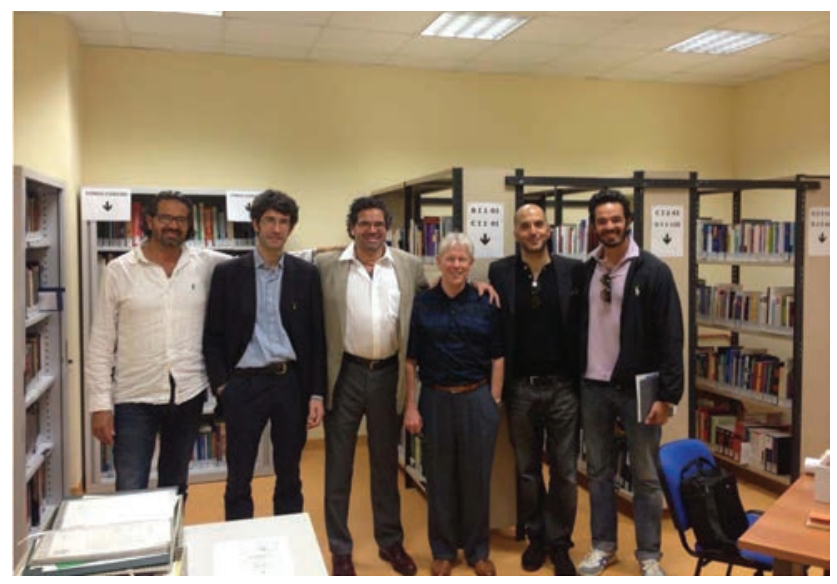

Figure 3. The International Union of Phlebology elected President Nick Morrison (fourth from left) visits together Marco Bresadola (second from left) and Sergio Gianesini (second from right) the Bassi International Library in Ferrara with members of Joseph Raffetto' family. 
who want to learn phlebology rather than to expert specialists. Now I am glad that you have preceded us. Your project meets the UIP's purpose. It is thus convenient that we abandon our project and bring it together with yours. I am very pleased to collaborate personally to this useful work and to give the official support of the Union's president. In the following months the project developed, as Bassi's correspondence and other material kept in his archive testify. Unfortunately, however, the publication of this new edition of the Compendium promoted by the UIP and written in English, never saw the light due to Bassi's death in December 1987.

Some months before dying Bassi published an article on the teaching of phlebology. He reviewed the state of the art in the three main fields of phlebological therapy that is surgery, sclerotherapy, and compression therapy. He acknowledged the advancements made in the previous three decades, but remarked that these progresses affected the practice of just a small number of physicians, while the majority of them still relied on wrong conceptions and outdated methods. Bassi called for the establishment of phlebology not only as a medical specialty but also as an autonomous discipline, with its own doctrinal body and teaching positions. He also stressed the fundamental role of the patient's attitude in the success of phlebological therapy, as the cure of veins' diseases needed prolonged times and the active collaboration of the patient. In his paper on the teaching of phlebology Bassi stressed the importance for an efficient therapy of treating the patient with psychology, tact, and perseverance, three fundamental qualities of the phlebologist but - we may add - of any physician. He then concluded his paper with the following words: Our generation has created phlebology. Next generation must educate phlebologists.

In the last twenty-five years since Bassi's death, phlebology has undergone many changes and its importance has been recognized in many countries. Once a specialty cultivated mainly in Europe, it has become a body of knowledge and therapeutic methods developed by physicians working in many other countries, and especially in the United States.
Today there are phlebological societies established in all continents, but the unifying core of all these scientific and promotional initiatives is still the International Union of Phlebology. The present conditions of phlebology, and its future development, are thus rooted in its history, which has been made by great figures of physicians, scientists, and organizers. There is no doubt that Glauco Bassi was one of these great figures.

Documents available at: the Bassi International Library of Phlebology,

clo Biblioteca delle Scienze della Salute, Azienda Ospedaliera Universitaria di

Ferrara,

via Aldo Moro 8, 44124 Loc. Cona, Ferrara,

Italy.

Tel.: +39.0532.236257 - Fax

+39.0532.236392.

E-mail: biblioteca@ospfe.it

Open from Monday to Friday; 9 a.m. - 4 p.m. 